\title{
Penerimaan Teknologi Web Check-In pada Pengguna Transportasi Udara di Kalimantan Barat
}

\author{
Assessing User Acceptance of Web Check in Service \\ on West Borneo Airline Passengers
}

\author{
Irawan Wingdes \\ STMIK Pontianak \\ E-mail: irawan.wingdes@gmail.com
}

\begin{abstract}
Abstrak
Teknologi check-in mandiri berbasis teknologi terutama dari web atau mobile telah tersedia sejak beberapa tahun lalu. Namun, penerimaan teknologi ini khususnya untuk pengguna di Kalbar, masih sangat rendah. Pada responden penelitian ini, hanya 7 persen responden yang pernah menggunakan fasilitas check-in tersebut. Oleh karena itu, penelitian ini bertujuan untuk menjelaskan faktor-faktor yang mempengaruhi penerimaan teknologi web check-in. Model TAM digunakan dengan menambahkan variabel trust dan risk. Data dianalisis dengan structural equation modeling. Hasil menunjukkan bahwa model fit dengan chi $^{2}$ yang tidak signifikan dan indikator goodness of fit yang baik. Persepsi kegunaan (nilai korelasi 0,41), dan persepsi resiko $(0,37)$ adalah variabel yang paling mempengaruhi niat untuk menggunakan web check-in, setelah itu diikuti oleh variabel kemudahan pemakaian $(0,33)$ dan kepercayaan $(0,32)$. Kontribusi penelitian bagi maskapai penyedia layanan adalah komunikasi merupakan kunci utama untuk meningkatkan penerimaan teknologi web check-in. Dengan penerimaan teknologi yang tinggi diharapkan efisiensi yang ditawarkan oleh teknologi ini juga dapat dimanfaatkan sepenuhnya, baik untuk layanan saat ini maupun untuk layanan di masa depan.
\end{abstract}

Kata Kunci - web check in, technology acceptance model, trust, risk.

\begin{abstract}
Technology based self check-in service (web or mobile based) has been made available for some time. For passengers in West Borneo, acceptance for this technology is low, particularly participants in this research. There are only $7 \%$ of passengers in this research who use this technology; hence, the purpose of this study is to explain factors affecting acceptance of web check-in service. Two variables are added (trust and risk) to the original TAM model and structural equation modeling is employed for analysis. Structural model is fit with insignificant chi $i^{2}$ and good results are achieved in goodness of fit indicators. Results show perceived usefulness $(0,41$ correlation) and risk $(0,37)$ to be the main contributing factors to explain acceptance of web check-in, followed by perceived ease of use $(0,33)$ and trust $(0,32)$. This research further contributes to air transport providers. Findings in this research suggest communication is the key aspect for air transport providers to increase technology acceptance. Increased technology acceptance will also increase benefits from what technology can offer today or in the future.
\end{abstract}

Keywords - web check in, technology acceptance model, trust, risk. 


\section{PENDAHULUAN}

Pengguna internet di Indonesia tahun 2014 mencapai 88,1 juta orang atau penetrasi sebesar 34,9\% dari total penduduk yang ada di Indonesia. Dari semua pengguna internet di Indonesia, $85 \%$ mengakses internet menggunakan telepon seluler, 32\% menggunakan laptop, $13 \%$ menggunakan tablet, dan pc sebesar 14\%. Penetrasi internet ditargetkan mencapai 50\% pada akhir tahun 2015 [1]. Semakin tingginya penetrasi internet akan meningkatkan aktivitas internet yang berhubungan dengan transportasi udara.

Hongkong mempunyai penetrasi internet mencapai $74,5 \%$ dari populasi. Pengguna internet di Hongkong memimpin di Asia khususnya pada penggunaan di telepon genggam (HP) yang mencapai $96 \%$, pengguna internet tersebut menggunakan internet sebagai alat booking, pembayaran, dan check in penerbangan atau aktivitas transportasi udara[2].

Karena perkembangan teknologi, bidang industri layanan telah mentransformasi pemberian layanan, dari ketemu muka menjadi layanan mandiri. Konsumen dapat memenuhi kebutuhan mereka akan layanan secara mandiri melalui internet, telepon atau anjungan tunai mandiri, seperti pada layanan pembelian tiket, penarikan dana, dan lain-lain. Layanan mandiri ini memberikan daya tarik, terutama bagi sejumlah besar organisasi untuk memberikan layanan yang standar, mengurangi biaya tenaga kerja, meningkatkan efisiensi dan kualitas dari operasi yang berhubungan dengan tatap muka konsumen [3].

Untuk industri penerbangan, layanan check in juga telah direvolusi - melalui kios, online, dan smartphone. Hal ini memungkinkan konsumen memangkas waktu yang diperlukan untuk antrian, dan di sisi lain membantu perusahaan penerbangan dan bandara untuk mengurangi biaya [4].

Penggunaan internet dan teknologi informasi lainnya oleh konsumen memungkinkan banyak perusahaan di industri pariwisata mendapatkan keunggulan kompetitif yang bernilai. Di Spanyol khususnya, kategori produk tiket pesawat, kereta api, kapal adalah produk yang paling banyak dibeli secara online [5].

Seiring banyaknya maskapai penerbangan yang menerapkan check in mandiri berbasis teknologi di seluruh dunia, maka adalah penting untuk mengerti mengapa pengguna menerima teknologi tersebut. Sama seperti pengguna dari negara lain atau daerah lain, pengguna di Kalbar juga diberikan fasilitas check in mandiri, tetapi penerimaan teknologi ini masih sangat rendah. Jumlah pengguna yang menggunakan teknologi ini hanya 7\%, sementara 93\% sisanya tidak pernah menggunakan. Penerimaan yang rendah pada responden di Kalbar ini menjadi pertanyaan utama pada penelitian ini, faktor apa yang mempengaruhi penerimaan teknologi web check in di Kalbar?

Penelitian ini berbeda dengan penelitian sebelumnya dimana pada penelitian ini hanya berfokus pada faktor kepercayaan dan persepsi resiko sebagai faktor utama yang menjelaskan penerimaan teknologi web check in pada responden di Kalbar. Kepercayaan dan persepsi resiko menjadi faktor utama karena layanan transportasi udara secara umum masih belum dapat dikatakan sempurna $[6,7,8]$. Kedua faktor ini akan menjadi penentu utama dalam penerimaan teknologi web check in yang juga sebenarnya membutuhkan kepercayaan tinggi pada proses interaksinya.

\section{METODE PENELITIAN}

Penelitian ini mengadopsi model penerimaan teknologi dari technology acceptance model atau TAM. Analisa TAM dipilih karena telah digunakan selama lebih dari 25 tahun, dan model ini digunakan terutama untuk menganalisa faktor adopsi teknologi [9]. TAM dikembangkan dari theory of reasoned action (TRA) [10]. Teori TAM mengemukakan bahwa niat menggunakan teknologi ditentukan oleh dua kepercayaan: persepsi kegunaan dan persepsi kemudahan pemakaian [11] (kedua persepsi untuk seterusnya disebut use dan ease) (gambar 1). 
Melalui banyak pengujian sebelumnya, use menjadi penentu utama dari niat menggunakan, dengan koefisien regresi standar sebesar 0,6, dan mampu menjelaskan varian sebesar $40-60 \%$, sementara niat untuk menggunakan teknologi (untuk seterusnya niat disebut intention) dapat dijelaskan variannya sebesar 34-52\% [12].

TAM telah berkembang sejak pertama kali dikemukakan, mulai dari perkembangan model awal atau TAM menjadi TAM2 sampai menjadi UTAUT (gambar 2), perkembangan lainnya adalah dengan ekstensi pada model awal TAM [13].

Salah satu modifikasi yang dilakukan adalah menambahkan ekstensi, kepercayaan dan resiko telah mempunyai pengaruh terhadap adopsi e-commerce [14], (untuk seterusnya disebut trust dan risk). Trust secara tidak langsung mempengaruhi intention melalui risk. Karena hubungan penelitian ini yang erat dengan e-commerce, model dari penelitian ini mengadopsi dua variabel trust dan risk untuk menjelaskan intention (gambar 3).



Gambar 1. Model TAM awal

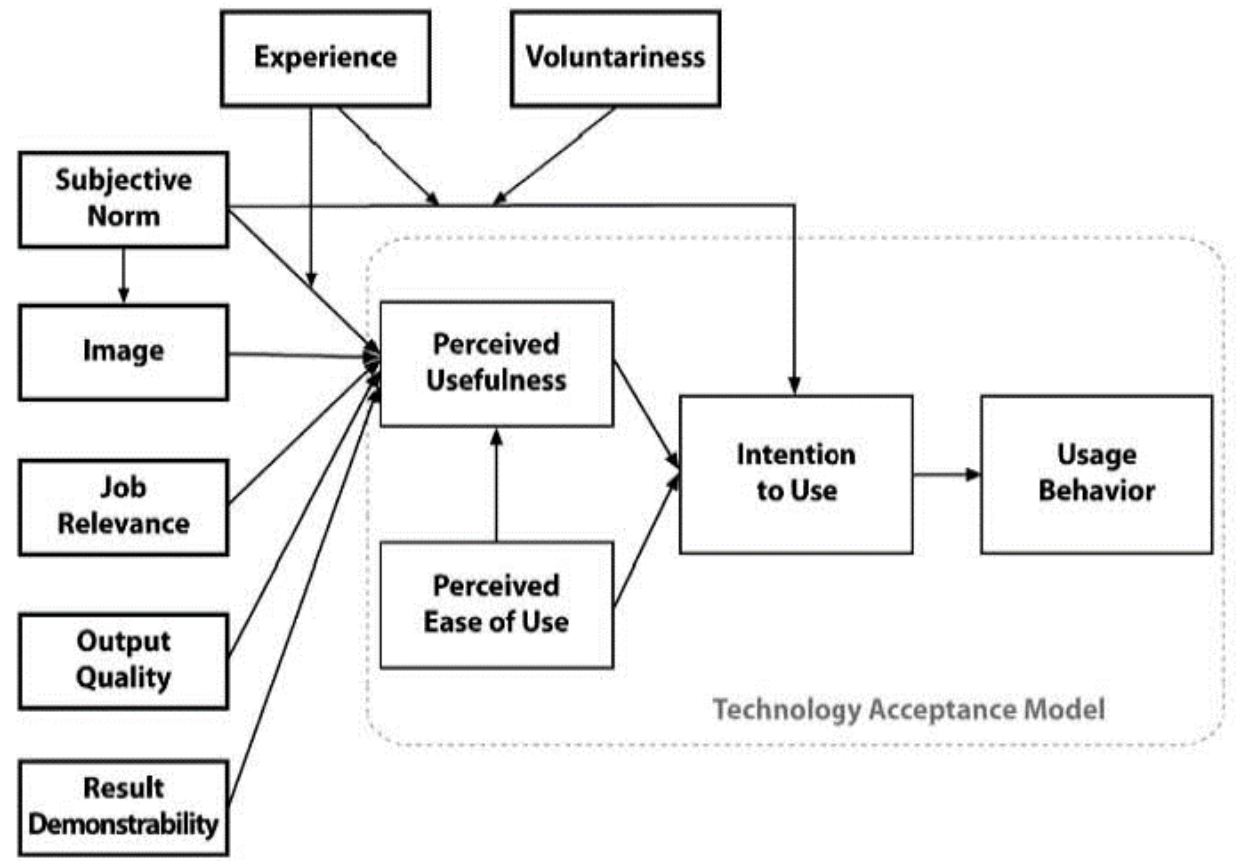

Gambar 2. Model TAM 2 


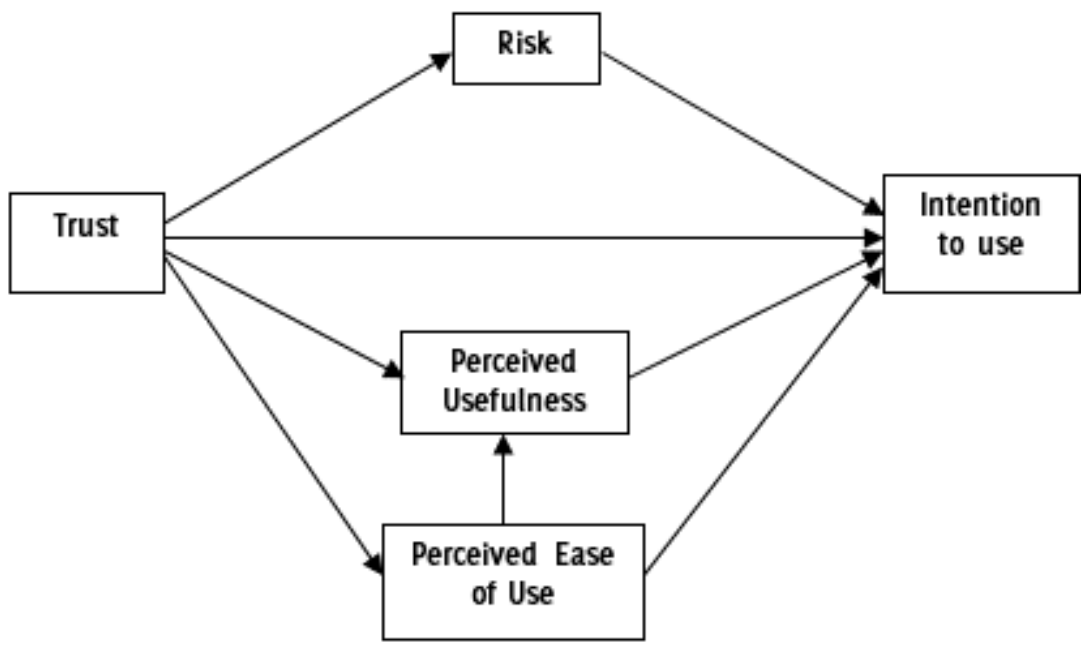

Gambar 3. Model penelitian

\subsection{Pembentukan Hipotesis}

\subsubsection{Trust}

Pada pembelian e-tiket di RRT, trust menunjukkan hasil yang penting, terutama pada pengguna yang baru [15]. Trust mempengaruhi secara langsung niat menggunakan, dan mempengaruhi secara tidak langsung melalui persepsi akan resiko [14].

Trust membantu mengurangi persepsi bahwa teknologi tidak berguna. Pada pembelian tiket biasanya konsumen langsung mendapatkan cetakan fisik, pada pembelian melalui internet, konsumen harus mencetak sendiri atau menunjukkan kode booking melalui HP kepada petugas. Bila tidak ada trust maka konsumen akan mempersepsikan pembelian tiket melalui internet sebagai sesuatu yang tidak berguna, karena itu trust mempengaruhi usefulness [15]. Pembelian tiket melalui internet sifatnya sama dengan melakukan check in melalui web sehingga hipotesis dirumuskan sebagai berikut:

\section{$\mathrm{H}_{1}$ : Trust mempengaruhi secara positif perceived usefulness.}

Trust juga mempengaruhi ease pada penelitian sebelumnya, kepercayaan menurunkan kompleksitas interaksi sehingga dipersepsikan interaksi tersebut mudah [14][15]. Untuk penelitian ini, hubungan ease dan trust dirumuskan sebagai berikut:

\section{$\mathrm{H}_{2}$ : Trust mempengaruhi secara positif perceived ease of use}

Trust mengurangi perceived risk terutama pada e-commerce, trust mengurangi ketidakpercayaan konsumen terhadap web tertentu, sehingga mengurangi ketidakpastian interaksi. [14]. Karena itu hubungan trust dan risk dirumuskan sebagai berikut

\section{$\mathrm{H}_{3}$ : Trust mempengaruhi secara negatif perceived risk pada web check in}

Trust merupakan instrumen penting pada penerimaan teknologi internet [16]. Konsumen yang tidak punya trust akan mengurangi niat untuk transaksi online [17]. Trust merupakan sesuatu yang penting pada e-commerce karena ketidakpastian yang tinggi pada transaksi online. Trust berhubungan positif dengan intention to transact [14]. Penggunaan web check in sifatnya sama dengan transaksi secara online, konsumen yang tidak percaya dengan teknologi web check in tidak akan menggunakan web check in karena faktor ketidakpastian seperti apakah check in berhasil, apakah check in dapat digunakan sepenuhnya pada saat di bandara nanti, atau apakah 
web check in benar-benar dapat diandalkan untuk menggantikan check in manual. Karena itu hubungan trust dan intention to use dirumuskan sebagai berikut:

\section{$\mathrm{H}_{4}$ : Trust mempengaruhi secara positif intention to use web check in}

\subsubsection{Risk}

Perceived risk atau ketidakpastian mempengaruhi keputusan konsumen. Situasi yang beresiko tinggi berhubungan dengan ketidakpastian tinggi yang dirasakan konsumen pada saat bertransaksi. Resiko terjadi pada saat teknologi gagal memberikan hasil, akan terjadi kerugian pada konsumen baik keuangan, psikologis, fisik atau sosial. [18].

Risk akan mengurangi intention untuk bertransaksi secara online [14]. Theory of reasoned action memperkirakan bahwa konsumen akan lebih berniat bertransaksi jika persepsi resiko mereka rendah. [14]. Karena itu resiko dirumuskan sebagai berikut:

$\mathrm{H}_{5}$ : Risk mempengaruhi secara negatif terhadap intention to use

\subsubsection{Ease}

Terdapat bukti yang kuat bahwa ease of use mempengaruhi intention to use, baik secara langsung ataupun secara tidak langsung melalui usefulness. [11, 12]. Dalam penelitian ini, ease of use diasumsikan sebagai kemudahan penggunaan web check in. Jika interaksi sederhana, gampang digunakan, dan tidak memerlukan keahlian tertentu, maka akan dipersepsikan berguna [15]. Dari kesimpulan tersebut, maka hubungan ease of use dirumuskan sebagai berikut:

$\mathrm{H}_{6}$ : Perceived ease of use mempengaruhi secara positif intention to use

$\mathrm{H}_{7}$ : Perceived ease of use mempengaruhi secara positif perceived usefulness

\subsubsection{Use}

Hasil pengujian TAM sebelumnya menunjukkan ada hubungan positif antara perceived usefulness dan intention to use [12,13].

Perceived usefulness menunjukkan penilaian pribadi akan kegunaan dari teknologi baru pada pekerjaan atau aktivitas. Dalam konteks web check in, usefulness dapat didefinisikan sebagai kegunaan baru yang bagi konsumen pada saat melakukan check in pesawat. Kegunaan baru dapat berupa kemudahan check in dimana saja, kapan saja melalui hp, kecepatan, maupun kepastian bahwa telah mendapatkan kursi di pesawat. Selain itu, waktu yang diperlukan untuk check in dapat dipersingkat karena tidak ada antrian. Penelitian di pengguna internet di Amerika mengemukakan bahwa bila pembelian tiket melalui internet dipersepsikan berguna, maka konsumen akan mempunyai intention to use yang tinggi. [15]. Karena itu hubungan antara perceived usefulness dan intention to use dapat dirumuskan sebagai berikut:

$\mathrm{H}_{8}$ : perceived usefulness mempengaruhi secara positif intention to use

\subsubsection{Intention}

Hubungan positif antara intention to use dan actual use telah diteliti di penelitian theory of reasoned action [10] dan theory of planned behavior [19]. Penelitian tentang TRA dan TAM juga telah menunjukkan hubungan yang positif antara intention to use dan actual use [15]. Dalam penelitian ini, actual use tidak diukur karena penerimaan dari web check in yang masih rendah pada responden, dalam penelitian ini hanya intention yang diukur dengan menggunakan empat variable sebelumnya, yaitu trust, risk, use dan ease. 


\subsection{Pengembangan Alat Ukur}

Alat ukur yang digunakan diambil dari penelitian sebelumnya yang mirip dan memang ditujukan untuk mengukur penerimaan teknologi e-commerce atau yang berhubungan dengan web. Mengingat web check in mengandalkan internet sepenuhnya, maka alat ukur digunakan dari penelitian sebelumnya yang mempunyai kesamaan. Ringkasan alat ukur (tabel 1) :

Tabel 1. Pengembangan alat ukur

\begin{tabular}{|c|c|c|}
\hline Item & Kuesioner & Literatur \\
\hline trust 1 & $\begin{array}{l}\text { Laman / website check in online yang disediakan maskapai dapat dipercaya } \\
\text { (misalnya check in online oleh Garuda, Lion, Sriwijaya) } \\
\text { Saya percaya laman / website check in online maskapai mampu memenuhi } \\
\text { fungsinya dalam hal check-in pesawat. }\end{array}$ & [14] \\
\hline risk2 & $\begin{array}{l}\text { Bagaimana anda menggambarkan resiko penggunaan check in online pada } \\
\text { maskapai yang anda gunakan jasanya? ( } 1 \text { beresiko tinggi -- } 7 \text { beresiko rendah) } \\
\text { Bagaimana anda menggambarkan keputusan anda menggunakan check in } \\
\text { online? } \\
\text { (1 sangat negatif -- } 2 \text { sangat positif) }\end{array}$ & [14] \\
\hline $\begin{array}{l}\text { use } 1 \\
\text { use } 2 \\
\text { use3 }\end{array}$ & $\begin{array}{l}\text { Menggunakan check in online membuat proses check in saya lebih efisien } \\
\text { Menggunakan check in online membuat proses check in saya lebih cepat } \\
\text { Menggunakan check in online berguna bagi perjalanan saya }\end{array}$ & {$[2][11]$} \\
\hline $\begin{array}{l}\text { ease1 } \\
\text { ease2 } \\
\text { ease2 }\end{array}$ & $\begin{array}{l}\text { Check in online mudah dipelajari } \\
\text { Mempelajari check in online tidak membutuhkan usaha berlebih bagi saya } \\
\text { Menggunakan check in online itu sederhana }\end{array}$ & {$[2][11]$} \\
\hline $\begin{array}{l}\text { intention } 1 \\
\text { intention2 } \\
\text { intention3 }\end{array}$ & $\begin{array}{l}\text { Saya berniat menggunakan check in online dikemudian hari } \\
\text { Saya berniat menggunakan secara rutin check in online pada perjalanan saya } \\
\text { di kemudian hari } \\
\text { Saya akan merekomendasikan orang lain untuk menggunakan online check in }\end{array}$ & {$[2][11][14]$} \\
\hline
\end{tabular}

\subsection{Skala Pengukuran}

Skala yang digunakan pada penelitian ini juga mengadopsi dari penelitian sebelumnya yaitu menggunakan skala likert dengan angka 1-7 dimana 1 sangat tidak setuju dan 7 sangat setuju. Khusus untuk risk, skala 7 adalah resiko terendah, skala 1 adalah resiko tertinggi.

\subsection{Sampling}

Sampling dilakukan dengan judgement sampling pada pengguna layanan transportasi udara di Kalbar. Responden disaring berdasarkan lama menetap di Kalbar dimana kuesioner hanya diberikan pada responden yang 10 tahun terakhir beraktivitas dan menetap di Kalbar. Responden tidak diseleksi lagi berdasarkan maskapai karena hampir semua penyedia layanan telah memberikan layanan web check-in. Pengguna layanan transportasi udara di Kalbar juga pada umumnya tidak tetap menggunakan layanan dari satu maskapai terus-menerus.

Terdapat tiga penyedia layanan transportasi udara utama di Kalbar, yaitu Garuda, Sriwijaya dan Lion. Dari 3 penyedia layanan transportasi udara utama di Kalbar, hanya Sriwijaya yang tidak menyediakan web check-in, tetapi disubstitusi dengan check-in berbasis teknologi 
mobile yang dapat diakses melalui BBM (Blackberry Messenger) dengan pin 574d5709, checkin melalui BBM ini sudah dimulai sejak tahun 2013. Untuk Garuda dan Lion, web check-in telah diberlakukan sejak tahun 2012, web check-in untuk Garuda dapat diakses di https://checkin.si.amadeus.net/1ASIHSSCWEBGA/sscwga/checkin?ln=en dan untuk Lion di https://wci-prod.sabresonicweb.com/SSW2010/JTC0/checkin.html?execution=e1s1.

\subsection{Pengumpulan Data}

Pengumpulan data dilakukan dengan metode survei dengan kuesioner. Sebagian kuesioner dibagikan di bandara utama di Pontianak, yaitu Supadio, dan sebagian lagi di beberapa jasa taxi yang mengantar penumpang ke bandara seperti Antya, Tegar, dan Tiga Bersaudara. Selain menanyakan pertanyaan kuesioner penelitian, data demografis juga dikumpulkan. Pengumpulan data dilakukan selama 2 bulan (april-mei 2015). Khusus untuk responden yang tidak pernah menggunakan web check in, responden diperagakan caranya dalam laptop/HP yang telah disimpan sebelumnya oleh peneliti.

\subsection{Alat Analisis Data}

Data dianalisis dengan structural equation modeling menggunakan software Lisrel 8.7. Structural equation modeling mempunyai dua tujuan utama, yaitu menentukan apakah model fit atau masuk akal, dan menguji berbagai hipotesis yang telah dibangun sebelumnya. [20]. Dalam penelitian ini, skala pengukuran diuji terlebih dahulu dengan confirmatory factor analysis, kemudian barulah keseluruhan struktur atau model dari penelitian.

SEM dianalisis dengan metode maximum likelihood. Tetapi chi square yang digunakan adalah chi square Satorra-Bentler yang telah disesuaikan khusus untuk data ordinal karena skala likert adalah skala ordinal [21]. Metode maximum likelihood yang telah disesuaikan untuk data ordinal dilakukan dengan memasukkan matrix asymptotic. Dengan demikian, analisis sem tetap valid walaupun data tidak normal karena data ordinal [20, 21].

\section{HASIL DAN PEMBAHASAN}

\subsection{Data Deskriptif Responden}

Dari 350 jumlah kuesioner yang dibagikan, yang dapat digunakan sebanyak 338 responden. Sebanyak 12 kuesioner tidak digunakan karena isinya ganda, kosong, dan tidak lengkap. Dari 338 responden, data deskriptif menunjukkan hanya 7\% yang pernah melakukan web check in. Hasil ini menjadi penanda bahwa teknologi web check-in masih belum diterima oleh masyarakat Kalbar. Umur tersebar mulai dari umur 15 sampai lebih dari 46 tahun. Asal daerah juga bervariasi dan hampir 50 persen berasal dari Pontianak (tabel 2).

\subsection{Evaluasi Model Pengukuran}

Confirmatory Factor Analysis dilakukan untuk menilai convergent validity dan discriminant validity dari model. Convergent validity melihat kemampuan sebuah indikator mengukur sebuah konstruk. Dikatakan valid jika nilai t-value $>1.96$ untuk tiap indikator dan standardized loading $>0.5$ untuk setiap indikator [5].

Discriminant validity dapat diukur dengan melihat composite reliability dan average variance extracted, untuk composite nilainya $>0.7$ dan untuk AVE nilainya $>0.5$ [5]. Hasil CFA dapat dilihat pada rangkuman tabel 3. CFA dilakukan menggunakan software LISREL 8.7. 


\subsection{Evaluasi Struktural Model}

SEM mempunyai dua tujuan utama dalam analisisnya, yang pertama evaluasi struktural atau evaluasi model plausible (masuk akal) atau fit dilakukan untuk melihat apakah model "benar" berdasarkan suatu data yang dimiliki dan tujuan kedua dari adalah untuk menguji berbagai hipotesis yang telah dibangun sebelumnya [20]. Hubungan antar konstruk dapat dilihat pada tabel 4 berikut ini, dengan keterangan yang dikurung adalah koefisien alpha cronbach. Evaluasi model fit digunakan beberapa indikator yaitu goodness of fit (tabel 5). Hasil pengujian hipotesis disajikan pada tabel 6 .

Tabel 2 Data Deskriptif Responden

\begin{tabular}{|c|c|c|c|c|c|c|c|c|}
\hline Gender & Frek & Persentase & Asal & Frekuensi & Persentase & Asal & Frek & Persentase \\
\hline Pria & 148 & 43.8 & Btg Tarang & 5 & 1.5 & Pontianak & 164 & 48.5 \\
\hline Wanita & 190 & 56.2 & Bengkayang & 7 & 2.1 & Putussibau & 12 & 3.6 \\
\hline Umur & & & Entikong & 3 & .9 & Rasau & 2 & .6 \\
\hline $15-25$ & 106 & 31.4 & K. Hulu & 16 & 4.7 & Sambas & 6 & 1.8 \\
\hline $26-35$ & 108 & 32.0 & Ketapang & 3 & .9 & Sanggau & 14 & 4.1 \\
\hline $36-45$ & 103 & 30.5 & Landak & 1 & .3 & Sekadau & 8 & 2.4 \\
\hline$>46$ & 21 & 6.2 & Mandor & 4 & 1.2 & Singkawang & 15 & 4.4 \\
\hline Pekerjaan & & & Melawi & 13 & 3.8 & Sintang & 17 & 5.0 \\
\hline Pelajar & 60 & 17.8 & Meliau & 1 & .3 & Sosok & 1 & .3 \\
\hline Pegawai & 121 & 35.8 & Mempawah & 9 & 2.7 & Sukadana & 8 & 2.4 \\
\hline Wiraswasta & 70 & 20.7 & Natuna & 1 & .3 & Tayan & 5 & 1.5 \\
\hline Lain-lain & 87 & 25.7 & Ngabang & 9 & 2.7 & Total & 338 & 100 \\
\hline \multicolumn{3}{|c|}{ Pernah Web Check In } & Pemangkat & 2 & .6 & & & \\
\hline $\mathrm{Ya}$ & 22 & 0.07 & Peniti & 2 & .6 & & & \\
\hline Tidak & 316 & 0.93 & Pinyuh & 10 & 3.0 & & & \\
\hline
\end{tabular}

Tabel 3 Hasil Pengujian alat ukur

\begin{tabular}{|c|c|c|c|c|c|c|c|}
\hline Variable & $\begin{array}{l}\text { Standardized } \\
\text { Loading }\end{array}$ & Error & t-value & Ket & $\begin{array}{l}\text { Composite } \\
\text { Reliability }\end{array}$ & $\begin{array}{l}\text { Average Varians } \\
\text { Reliability }\end{array}$ & Ket \\
\hline Trust 1 & 0.68 & 0.54 & 9.64 & Valid & \multirow{2}{*}{0.74} & \multirow{2}{*}{0.58} & \multirow{2}{*}{ Reliable } \\
\hline Trust 2 & 0.84 & 0.29 & 11.27 & Valid & & & \\
\hline Risk1 & 0.75 & 0.43 & 12.22 & Valid & \multirow{2}{*}{0.78} & \multirow{2}{*}{0.63} & \multirow{2}{*}{ Reliable } \\
\hline Risk2 & 0.84 & 0.30 & 13.48 & Valid & & & \\
\hline Ease1 & 0.74 & 0.45 & 17.92 & Valid & \multirow{3}{*}{0.80} & \multirow{3}{*}{0.58} & \multirow{3}{*}{ Reliable } \\
\hline Ease2 & 0.70 & 0.51 & 16.99 & Valid & & & \\
\hline Ease3 & 0.83 & 0.31 & 21.34 & Valid & & & \\
\hline Use 1 & 0.78 & 0.39 & 20.08 & Valid & 0.80 & 0.57 & Reliable \\
\hline Use2 2 & 0.71 & 0.50 & 17.18 & Valid & & & \\
\hline Use3 & 0.78 & 0.39 & 22.5 & Valid & & & \\
\hline Intention 1 & 0.75 & 0.43 & 24.95 & Valid & \multirow{3}{*}{0.86} & \multirow{3}{*}{0.68} & \multirow{3}{*}{ Reliable } \\
\hline Intention 2 & 0.91 & 0.18 & 41.45 & Valid & & & \\
\hline Intention 3 & 0.80 & 0.35 & 29.84 & Valid & & & \\
\hline
\end{tabular}


Citec Journal, Vol. 3, No. 1, November 2015 - Januari 2016

Tabel 4. Korelasi antar konstruk

\begin{tabular}{|c|c|c|rrrrr|}
\hline & Mean & SD & \multicolumn{1}{c|}{ Risk } & Ease & Use & Intention & Trust \\
\hline Risk & 3.936 & 1.183 & $(0.733)$ & & & & \\
Ease & 4.143 & 1.154 & 0.01 & $(0.772)$ & & & \\
Use & 4.838 & 1.184 & 0.02 & 0.12 & $(0.767)$ & & \\
Intention & 4.530 & 1.063 & 0.37 & 0.33 & 0.41 & $(0.830)$ & \\
Trust & 3.858 & 1.099 & 0.19 & 0.04 & 0.1 & 0.32 & $(0.707)$ \\
\hline
\end{tabular}

Tabel 5. Penilaian struktural goodness of fit

\begin{tabular}{|l|l|l|}
\hline Penilaian goodness-of-fit & Nilai dianjurkan & Hasil \\
\hline chi $^{2}$ / degree of freedom & $<3$ & 1.007 \\
Goodness-of-fit-index (GFI) & $>=0.9$ & 0.96 \\
Adjusted goodness-of-fit (AGFI) & $>=0.8$ & 0.94 \\
Normed fit index (NFI) & $>=0.9$ & 0.97 \\
Root mean square residual (RMSR) & $<=0.1$ & 0.063 \\
Root mean square error of approximation & $<=0.06$ atau & \\
(RMSEA) & 0.08 & 0.005 \\
\hline
\end{tabular}

Tabel 6. Ringkasan penerimaan/penolakan hipotesis

\begin{tabular}{|l|l|}
\hline \multicolumn{1}{|c|}{ Hipotesis } & Terima/tolak \\
\hline $\mathrm{H}_{1}:$ Trust mempengaruhi secara positif perceived usefulness. & Tolak \\
\hline $\mathrm{H}_{2}:$ Trust mempengaruhi secara positif perceived ease of use & Tolak \\
\hline $\mathrm{H}_{3}:$ Trust mempengaruhi secara positif perceived risk pada web check in & Terima \\
\hline $\mathrm{H}_{4}:$ Trust mempengaruhi secara positif intention to use web check in & Terima \\
\hline $\mathrm{H}_{5}:$ Risk mempengaruhi secara negatif intention to use & Terima \\
\hline $\mathrm{H}_{6}:$ Perceived ease of use mempengaruhi secara positif intention to use & Terima \\
\hline $\mathrm{H}_{7}:$ Perceived ease of use mempengaruhi secara positif perceived usefulness & Tolak \\
\hline $\mathrm{H}_{8}:$ Perceived usefulness mempengaruhi secara positif intention to use & Terima \\
\hline
\end{tabular}

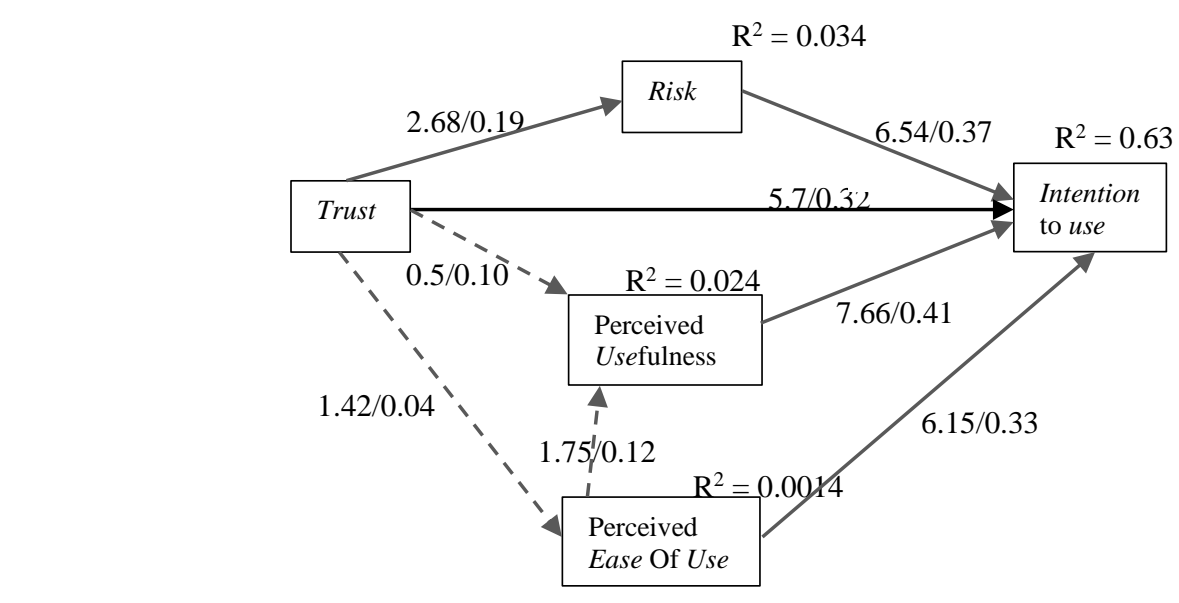

$\mathrm{p}<1.96$ tidak signifikan (garis putus ${ }^{2}$ )

$\mathrm{p}>1.96$ signifikan (garis langsung)

$\mathrm{Chi}^{2}$ 57.44, p=0.46, RMSEA 0.005

Gambar 4. Hasil Pengolahan data

Pada evaluasi model pengukuran, tujuan utama adalah untuk menentukan validitas dan reliabilitas indikator-indikator dari suatu konstruk [20]. Dari tabel 3 dapat dilihat bahwa semua indikator telah memenuhi kriteria dari convergent validity dan discriminant validity. Untuk convergent validity, nilai t-value diatas 1.96 pada setiap indikator dan standardized loading semuanya di atas 0,5 . Sedangkan discriminant validity yang dinilai dari composite reliability dan average variance extracted semuanya diatas 0,7 dan 0,5 . 
Hasil chi $^{2}$ Satorra-Bentler menunjukkan nilai 57,44 dengan probabilitas tidak signifikan pada angka $\mathrm{p}=0,46$. Sedangkan chi $^{2}$ corrected for non-normality menunjukkan nilai 58.65 yang juga tidak signifikan pada angka $\mathrm{p}=0,41$. Hasil kedua $\mathrm{chi}^{2}$ yang sudah dikoreksi untuk data tidak normal menunjukkan bahwa model sudah fit.

Untuk $\mathrm{chi}^{2} /$ degrees of freedom, hasil menunjukkan nilai 1,007 sehingga sudah di bawah angka rekomendasi yaitu 3. GFI juga menunjukkan nilai 0,96, dan RMSEA menunjukkan angka 0,005 yang semuanya berada di bawah batas yang direkomendasikan sehingga dapat disimpulkan bahwa model sudah fit.

Dengan hasil SEM, terdapat 3 hipotesis yang ditolak, yaitu trust ke use, trust ke ease dan ease ke use. Sementara 5 hipotesis lainnya diterima. Masing-masing hubungan dapat dijelaskan sebagai berikut: Trust tidak signifikan hubungannya dengan ease dan use. $\mathrm{R}^{2}$ dari use sebesar 0.024 sementara ease sebesar 0.0014. Trust signifikan berhubungan dengan risk dengan nilai $\mathrm{R}^{2}$ 0.034 dan nilai korelasi sebesar 0.19 yang menandakan hubungan cukup kuat. Use tidak signifikan hubungannya dengan ease, dengan nilai $\mathrm{R}^{2}$ sebesar 0.024 . Dalam penelitian ini, dapat disimpulkan bahwa ease tidak menjadi penentu dari use. Intention mempunyai $\mathrm{R}^{2}$ sebesar $63 \%$ dari gabungan use, risk, ease dan trust. Masing-masing menunjukkan hubungan yang kuat dengan korelasi sebesar $0.41,0.37,0.33$ dan 0.32 .

\subsection{Pembahasan}

Trust signifikan mempengaruhi secara langsung intention dan secara tidak langsung melalui risk. Hasil ini konsisten dengan penelitian sebelumnya [14, 22], kepercayaan terhadap maskapai pemberi layanan menjadi faktor yang mempengaruhi niat untuk menggunakan teknologi web check in. Kepercayaan juga mempengaruhi persepsi resiko, dimana kepercayaan yang tinggi maka akan menurunkan persepsi resiko penggunaan web check in.

Trust tidak signifikan dan lemah mempengaruhi use dan ease. Hasil ini mempunyai 4 kemungkinan, yaitu responden percaya dan merasa teknologi berguna / mudah, responden tidak percaya tetapi merasa teknologi berguna / mudah, responden percaya tetapi merasa teknologi tidak berguna / tidak mudah, dan terakhir responden tidak percaya dan merasa teknologi tidak berguna / tidak mudah. Dari mean di use yang bernilai 4,8, dapat disimpulkan bahwa rata-rata responden cenderung merasa teknologi ini berguna. Mean dari trust bernilai 3.8 sehingga responden juga dapat diasumsikan rata-rata cenderung percaya. Sedangkan mean dari ease bernilai 4,1 juga menunjukkan hasil yang cenderung ke arah mudah digunakan. Hasil yang tidak signifikan pada hubungan trust terhadap use dan ease mengindikasikan ada variabel lain yang perlu dieksplorasi, kesimpulan ini juga didukung oleh $\mathrm{r}^{2}$ pada trust terhadap use dan ease yang masing-masing kurang dari $3 \%$.

Hasil trust terhadap use dan ease pada penelitian ini berbeda dengan penelitian sebelumnya. Pada penelitian sebelumnya, laman yang gampang dimengerti akan meningkatkan kepercayaan pengguna karena itu merupakan sinyal bahwa penyedia serius akan layanannya dan berusaha membuat laman penyedia jasanya lebih mudah dimengerti. Usaha dan keseriusan penyedia layanan diterjemahkan secara tidak langsung sebagai sesuatu yang meningkatkan kepercayaan [23]. Selain itu kepercayaan dianggap mempengaruhi kemudahan pemakaian karena apabila pengguna percaya dengan penyedia layanan maka konsumen tidak curiga pada saat berinteraksi sehingga secara tidak langsung membuat interaksi menjadi lebih mudah [14].

\subsubsection{Risk}

Persepsi resiko signifikan mempengaruhi niat untuk menggunakan layanan web check in. Hasil ini konsisten dengan penelitian sebelumnya [2, 14]. Variabel resiko adalah salah satu faktor yang paling menentukan niat untuk menggunakan teknologi web check-in dengan korelasi 0,37. 


\subsubsection{Ease}

Ease tidak signifikan mempengaruhi use atau kemudahan pemakaian tidak mempengaruhi persepsi kegunaan. Hasil ini juga berbeda dengan penelitian sebelumnya. Pada penelitian sebelumnya, apabila laman mudah digunakan maka persepsi kegunaan juga akan tinggi [14].

Ease signifikan dan kuat mempengaruhi intention. Hasil ini konsisten dengan penelitian sebelumnya [14, 22, 23, 24]. Apabila web check-in mudah digunakan, maka pengguna akan lebih berniat menggunakan.

\subsubsection{Use}

Use dalam penelitian ini kuat dan signifikan mempengaruhi intention, persepsi bahwa teknologi itu bermanfaat akan mempengaruhi niat untuk menggunakan teknologi tersebut $[2,5$, $13,15,25]$. Dari semua variabel lain, variabel inilah yang paling kuat mempengaruhi intention dengan koefisien korelasi sebesar 0,41.

Hasil penelitian ini berkontribusi bagi maskapai pemberi layanan dari beberapa sisi. Dari sisi trust dan risk, maskapai dapat meningkatkan kepercayaan pengguna dengan publikasi dan komunikasi yang tepat. Publikasi intensif dapat dilakukan untuk menjangkau pengguna baru. Sedangkan komunikasi dapat dilakukan untuk memberikan jaminan keakuratan dan keandalan web check-in.

Komunikasi keakuratan dan keandalan perlu dilakukan secara intensif supaya web check in dapat dipersepsikan sebagai sesuatu yang sama seperti check-in konvensional dimana pengguna tidak perlu khawatir akan keabsahan tiket, kesalahan penempatan duduk ataupun masalah sederhana tetapi penting seperti masalah bagasi.

Publikasi untuk menjaring pengguna baru, komunikasi keakuratan dan keandalan untuk pengguna yang akan mengadopsi, akan meningkatkan trust, mengurangi risk, meningkatkan ease dan pada akhirnya menambah use sehingga intention akan semakin tinggi dan teknologi ini dapat diterima secara luas.

Pada saat manfaat dari web check in telah dirasakan oleh pengguna karena penerimaan teknologi ini sudah tinggi, maka teknologi lanjutan dapat diterapkan untuk mengurangi biaya dan meningkatkan efisiensi, salah satunya adalah dengan menerapkan kios check in atau anjungan check-in mandiri yang dapat mengurangi biaya operasional maskapai [2].

\section{KESIMPULAN}

Penelitian ini berhasil memadukan variabel kepercayaan dan variabel persepsi resiko pada model TAM untuk menilai penerimaan web check-in. Model fit dengan chi ${ }^{2}$ Satorra-Bentler yang tidak signifikan pada $\mathrm{p}=0,46$ serta indikator goodness of fit yang baik. Keempat variabel yang dibangun yaitu Trust, Risk, Ease, dan Use mempengaruhi secara kuat dan signifikan terhadap Intention dengan korelasi tertinggi pada use $(0,41)$, diikuti risk $(0,37)$, ease $(0,33)$ dan trust $(0,32)$. Keempat variabel berhasil menjelaskan variabilitas pada variabel intention sebesar $63 \%$.

Pengguna akan berniat menggunakan teknologi web check-in apabila percaya dengan website penyedia layanan, berpandangan bahwa resiko penggunaan web check-in itu rendah, menganggap interaksi dengan website check-in mudah, dan yang paling penting adalah mempunyai persepsi bahwa menggunakan web check-in adalah pilihan yang bermanfaat. Publikasi dan komunikasi oleh maskapai perlu ditingkatkan sehingga penerimaan teknologi ini lebih baik dan efisiensi yang timbul karena teknologi ini juga sesuai.

Hubungan trust terhadap ease dan use yang tidak signifikan juga memberikan tambahan informasi yaitu persepsi kepercayaan pengguna web check in tidak semata-mata hanya dipengaruhi oleh website check-in tersebut saja, melainkan ada faktor lain. Kemudahan 
pemakaian juga tidak semata-mata dipengaruhi oleh kemudahan mengoperasikan website checkin melainkan ada faktor lain yang perlu dieksplorasi lebih lanjut.

\section{SARAN}

Kekurangan yang juga merupakan kelebihan dari penelitian ini, adalah pada modelnya yang parsimoni atau sederhana. Model sederhana dapat menjelaskan lebih akurat, tetapi terdapat kekurangan karena tidak terlalu banyak yang dapat dijelaskan. Koefisien alpha masih dapat ditingkatkan dengan menambah indikator-indikator tambahan pada setiap konstruk.

Pada indikator di trust, dapat dikembangkan indikator tambahan seperti pengalaman pengguna sebelumnya terhadap maskapai penerbangan yang mereka gunakan. Sedangkan untuk indikator pada ease dapat dikembangkan dari sisi kemudahan ataupun kenyamanan akses kapan saja dimana saja yang ditawarkan oleh teknologi mobile. Pada penelitian selanjutnya juga dapat dikembangkan pengujian berdasarkan kelompok dimana pengelompokan responden dapat dilakukan berdasarkan umur, asal daerah, pekerjaan, atau kefasihan dalam menggunakan teknologi.

\section{UCAPAN TERIMA KASIH}

Penulis mengucapkan terima kasih kepada STMIK Pontianak yang telah memberi dukungan finansial terhadap penelitian ini.

\section{DAFTAR PUSTAKA}

[1] Pangerapan, S. A., 2015, Siaran Pers (press release) Asosiasi Penyelenggara Jasa Internet Indonesia (APJII), http://www.apjii.or.id/v2/read/content/info-terkini/301/penggunainternet-indonesia-tahun-2014-sebanyak-88.html, diakses 27 Maret 2015.

[2] Kucukusta, D., Law, R., Besbes, A., Legohérel, P., 2015, Re-examining perceived usefulness and ease of use in online booking -- the case of hongkong online user, International Journal of Contemporary Hospitality Management, No. 2, Vol. 27, Hal. 185-198.

[3] Lu, J. L., Chou, H. Y., Ling P. C., 2009, Investigating passengers' intention to use technologybased self check-in services, Transportation Research Part E, No. 2, Vol 45, hal 345-356.

[4] Peterson, K., 2006, Self-service top ten. Airport Business, http://www.aviationpros.com/article/10382775/self-service-top-ten, diakses 30 Maret 2015.

[5] Rodriguez, T. E., Trujillo E. C., 2014, Online purchasing tickets for low cost carriers: An application of unified theory of acceptance and use of technology (UTAUT) model, Tourism Management, Vol 43, Hal 70-88.

[6] Rahayu, R. N., 2015, Ratusan Calon Penumpang Lion Air Ngamuk di Soekarno-Hatta, okezone.com, http://news.okezone.com/read/2015/02/19/338/1107966/ratusan-calonpenumpang-lion-air-ngamuk-di-soekarno-hatta, diakses 27 Maret 2015.

[7] Herin, F.P., 2014, Garuda Tunda Lagi Jadwal Keberangkatan, Penumpang Marah, kompas.com,http://regional.kompas.com/read/2014/12/02/09224801/Garuda.Tunda.Lagi.J adwal.Keberangkatan.Penumpang.Marah, diakses 28 Maret 2015.

[8] Foni, Y., 2014, Pesawat Terlambat Dua Jam, Penumpang Sriwijaya Maki Petugas, metrotvnews.com, $\quad$ http://news.metrotvnews.com/read/2014/12/31/338818/pesawatterlambat-dua-jam-penumpang-sriwijaya-maki-petugas, diakses 29 Maret 2015. 
[9] Nysveen, H., Pedersen. P., Thorbjornsen, H., 2005, Explaining intention to use mobile chat services: moderating effects of gender, Journal of Consumer Marketing, No. 5, Vol. 22, Hal. 247-256.

[10] Fishbein, M. dan Ajzen, I., 1975, Belief, Attitude, Intention and Behavior: An introduction to Theory and Research, Addison-Wesley Reading.

[11] Davis, F. D., 1989, Perceived usefulness, perceived ease of use, and user acceptance of information technology, MIS Quaterly, No 3, Vol 13, Hal. 319-340.

[12] Venkatesh, V., Davis, F., 2000, A theoretical extension of the technology acceptance model: four longitudinal field studies, Management Science, No 2, Vol. 46, hal 186-204.

[13] Marangunic, N., Granic, A., 2014, Technology acceptance model: a literature review from 1986 to 2013, Universal Access in the Information Society, No. 1, Vol 14, hal 81-95.

[14] Pavlou, P. A., 2003, Consumer acceptance of electronic commerce: integrating trust and risk with the technology acceptance model, International Journal of Electronic Commerce, No 3, Vol 7, Hal 69-103.

[15] Lee, C. B. P., Wan, G., 2010, Including subjective norm and technology trust in the technology acceptance model: a case of e-ticketing in china, The Database for advances in information systems, No. 4 Vol. 4, Hal 40-51.

[16] Gefen, D., 2000, E-commerce: The role of familiarity and trust, Omega: The international journal of management science, No. 6, Vol. 28, Hal 725-737.

[17] Hoffman, D. L., Novak, T.P., Peralta, M., 1999, Building consumer trust online, Communications of the ACM, No. 4, Vol 42, Hal 80-85.

[18] Im, I., Kim, Y., Han, H. J., 2008, The effects of perceived risk and technology type on users' acceptance of technologies, Information and Management, No. 1, Vol 45, Hal 1-9.

[19] Ajzen, I., 1985, From intentions to actions: a theory of planned behavior, Action Control: From Cognition to Behavior, Springer Verlag.

[20] Ghozali, I., Fuad, 2014, Structural equation Modelling, teori konsep dan aplikasi dengan program lisrel 9.1 edisi 4, Badan Penerbit Universitas Diponegoro.

[21] Joreskoq, K. G., 2002, Structural Equation Modelling with ordinal variables using lisrel, Scientific Software International.

[22] Morosan, C., 2014, Toward an integrated model of adoption of mobile phones for purchasing ancillary services in air travel, International journal of contemporary hospitality management, No. 2, Vol 26, Hal 216-271.

[23] Gefen, D., Karahanna, E., Straub, D. W., 2003, Trust and TAM in online shopping: an integrated model, MIS Quaterly, No. 1, Vol 27, Hal 51-90.

[24] Davis, F., Bagozzi, R. P., Warshaw, P. R., 1989, User Acceptance of computer technology: a comparison of two theoretical models, Management Science, Vol 35, No 8, hal 982-1003.

[25] Edward, C. S., Ku, Chen, C. D., 2013, Fitting facilities to self service technology usage: evidence from kiosks in Taiwan airport, Journal of Air Transport Management, Vol 32, Hal 87-94. 